\title{
Bioactive Compounds from Medicinal Plants and Their Importance in Drug Discovery in Pakistan
}

Ghulam Mustafa ${ }^{1,2^{*}}$, Rawaba Arif ${ }^{1}$, Asia Atta $^{3}$, Sumaira Sharif ${ }^{4}$ and Amer Jamil ${ }^{1}$

${ }^{1}$ Department of Biochemistry, University of Agriculture, Faisalabad-38040, Pakistan

${ }^{2}$ Department of Bioinformatics and Biotechnology, Government College University, Faisalabad-38000, Pakistan

${ }^{3}$ Department of Biochemistry, Bahauddin Zakariya University, Multan-60800, Pakistan

${ }^{4}$ Department of Biochemistry and Molecular Biology, University of Gujrat, Gujrat-50700, Pakistan

*Corresponding author: gmustafa_uaf@yahoo.com

This is an open access article distributed under the Creative Commons Attribution License, which permits unrestricted use, distribution, and reproduction in any medium, provided the original work is properly cited.

\section{ARTICLE DETAILS}

Article history:

Received 22 January 2017

Accepted 03 February 2017

Available online 05 February 2017

Keywords:

medicinal plants; northern areas; Cholistan desert; secondary metabolites; biochemical profiling

\section{ABSTRACT}

Humans have relied on nature throughout their ages to cater for their basic needs including medicines to cure a wide spectrum of diseases. Plants have formed the basis for sophisticated systems of traditional medicines. For therapeutic agents many of the presently known lead compounds are natural products or their derivatives. Ethnomedicinal studies play a vital role to discover new drugs from indigenous medicinal plants. Green pharmaceuticals are getting popularity and extraordinary importance because vast opportunities for new drug discoveries are provided by the unmatched availability of chemical diversity and natural products either as pure compounds or as homogenous plant extracts. Therefore, in recent years the demand for herbal medicines and several natural products from a variety of plant species is consistently increasing. In spite of being an agricultural country and having different ecological regions, the medicinal plants of Pakistan have not been explored for their secondary metabolites which are responsible for treating different diseases. Although, huge importance of different extracts of medicinal plants from Pakistan have been reported for their different activities such as antimicrobial, anti-cancerouse, antiviral and antioxidant but complete biochemical profiling of these medicinal plants is lacking. LC-MS and GC-MS techniques have been applied in the field of drug discovery from medicinal plants but in Pakistan its success rate is very low in the subject of biochemical profiling. Therefore, such techniques should be used in Pakistan to explore active constituents from medicinal plants which could be used as medicines in future.

\section{Role of plants in drug discovery}

Medicinal plants have been used as a source of medicine in all cultures since times immemorial [1]. Initially plants were used by the people to meet their nutritional requirements. The natural flora became a very useful source for health improvement and to cure many diseases across various human communities and a variety of plants species are offered which are still in use in many parts of the world such as Asia [2], South America [3] and Africa [4] for remedies against several diseases. Even though World Health Organization reported that the primary health care system for the $60 \%$ population of the world is represented by the traditional medicines yet a great number of plant species with potential biological activities were unexplored [5]. The effectiveness of traditional medicines is now a putative fact because of their better compatibility with human body, better cultural acceptability in all over the world and lesser side effects [6]. In various human cultures around the world more than 35,000 plant species are being used for their medicine purposes [7] and for primary health care nearly $80 \%$ of the world populations rely on these traditional medicines which include the use of plant extracts most of the time [8].

Ethnomedicinal studies play a vital role to discover new drugs from indigenous medicinal plants and green pharmaceuticals are getting popularity and extraordinary importance [9] because vast chances for new drug discoveries are provided by the unrivaled availability of chemical diversity and natural products either as pure compounds or as homogenous plant extracts [10]. A decade ago the synthetic drugs because of unanticipated side effects were approved as safe and effective and had to be recalled and relabeled. The herbal medicines on the other hand, have no such adverse effects and because of combinations of medicinal constituents coupled with minerals and vitamins have benefits over synthetic ones [11]. In current scenario, the attention of scientists has been diverted towards ethnomedinices due to the revival of knowledge in customary health practices throughout the world. Therefore, in recent years the demand for herbal medicines and several natural products from a variety of plant species is consistently increasing. A number of modern drugs have been discovered since the history of ethnobotany paying a distinct importance to the documentation of traditional information of medicinal plants. From medicinal plants $78 \%$ of new chemical constituents being natural or natural product-derived molecules are being used as a promising alternative treatment for infectious diseases [12]. In modern pharmacopeia about $25 \%$ drugs and also a great number of synthetic analogs prepared on proto-type compounds which have been derived from plants are included [13].

Plants have an immense importance in the field of medicines because they have been utilized in medicines for the treatment of so many diseases for thousands of years [14]. Beginning with morphine which was isolated from opium in the early 19 th century, now active compounds are also isolated from medicinal plants [14-15]. Earlier, when the role of medicinal plants in drugs was discovered then a number of drugs were isolated such as codeine, cocaine, quinine, digitoxin and morphine. Some of these drugs are still in our use $[14,16]$. The extracts of several medicinal plants are very effective against microbial as well as parasitic infections [17]. For example, several groups of antifungal proteins like glucanase, chitinase and proteins which are of low molecular weight and non-enzymatic in nature are present in the seeds of many medicinal plants and these proteins are being used for the protection of a developing embryo from many infections [18].

Importance has been given to ethnobotany field in Pakistan [19] and a few studies have been done recently [20-21] but the treasure of medicinal plants is being vanished with the passage of time and measures are still needed to save it [21]. Pakistan is very rich in botanical wealth and has variety of medicinal and aromatic plants because of its exceptional phytogeography with varied climatic and edaphic factors such as soil conditions and multiple ecological regions. Out of 5700 about 400-600 species of medicinal plants are estimated to be found in Pakistan and only a small percentage of which have been biochemically investigated [22]. In the early 1950s, for their basic healthcare needs about $84 \%$ population of Pakistan was relying on traditional medicines [13] but now due to modernization and urbanization the practice is limited only in the remote areas [23]. Most medicinal plants from Pakistan are confined to the mountainous areas and then desert areas. A total of 1572 genera and 5521 species are identified in Pakistan having medicinal values for many diseases [24]. To enlist the applications of these indigenous medicinal plants a very few attempts have been made [25] and the information is incomplete as very few common plants are listed.

\section{Biochemical profiling and related techniques}

In an organism the presence of complete complement of small molecules is called metabolome [26]. Various terms such as metabolomics, metabonomics, metabolic fingerprinting and metabolic profiling have been defined throughout the years. The variations in metabolite fluxes are revealed by metabolomics and therefore it is the decisive level of postgenomic analysis. Minor changes within gene expression is responsible to control these metabolite fluxes and transciptomics and/or proteomic analysis are the methods to measure these changes while the analyses reveal post-translational control over the activity of enzyme involved. The high-throughput qualitative screening of a tissue or an organism with an analysis of sample comparison and discrimination as a main objective is called metabolite fingerprinting [26]. The biochemical status of an 
organism is revealed by the measurements of intracellular metabolites which would be qualitative or quantitative. These measurements in turn can be used to assess and monitor the functions of different genes [27] Different approaches are used to detect and investigate metabolome. For metabolic fingerprinting, liquid chromatography-mass spectrometry (LCMS) and proton nuclear magnetic resonance (1H NMR) are frequently used techniques. In various fields of plant research, LC-MS as a technique for fingerprinting was applied such as plant biochemistry [28], food chemistry [29], chemotaxonomy [30] and for establishing a control over quality of medicinal plants [31]. Over the past 50 years, spectroscopic techniques coupled with some good extraction methods like chromatography have contributed natural product chemistry to a phenomenal success. Gas chromatography (GC) and liquid chromatography coupled to mass spectrometry (GC- and LC-MS) are the most suited equipment for fast and comprehensive analysis of ultracomplex metabolite samples [32]. Using LC the separation of the thousands of molecules present in biofluids can reduce ion suppression [33] by decreasing the number of competing analytes entering the mass spectrometer ion source at a time. This results in a selective approach that allows quantification and structural information, where sensitivities in the $\mathrm{pg} / \mathrm{mL}$ range can be achieved readily [34]. LC/MS technique has replaced some of the specialized methods which have been practicing in traditional clinical laboratories [35] that used immunological, fluorometric, and biological techniques [36]. High sensitivity and selectivity are the main advantages of LC/MS that allow quantitative analysis of secondary metabolites in complex biological matrices at very low concentrations [37].

\section{History of medicinal plants}

Botanical medicine or phytomedicine, also called herbal medicine is the use of plants' seeds, roots, berries, leaves, flowers or bark for healthcare and they have been used since the prehistoric times by the people worldwide to treat, control and manage a variety of diseases [38-39]. Today, the infectious diseases have become worldwide a leading cause of death, therefore, their study has become a global concern [40]. The emergence of multidrugresistance in the pathogens is threatening the clinical efficiency of many existing antibiotics [41]. It is a matter of fact that a number of infectious diseases have been treated with herbal medicines throughout the history of mankind. Due to incomparable availability of the chemical diversity, the plant extracts either as standardized natural products or as pure compounds have been providing unlimited prospects for new drugs. It is an urgent and continuous need that new antimicrobial compounds should be discovered having novel mechanisms of action and diverse chemical structures for re-emerging and new infectious diseases [42]. Therefore, the attention of a number of researchers towards folk medicines is increasing continuously and they are trying to develop better drugs with antimicrobial activities [43]. A continuous increase in the failure of antibiotic resistance and chemotherapeutics exhibited by the pathogenic microbial infectious agents has enhanced the importance of medicinal plants and they have been screening out for their potential antimicrobial activity [44].

Scientists began to isolate, purify and identify active constituents (principles) from medicinal plant extracts during the late nineteenth century and these efforts led them to find some of the vital drugs from medicinal plants which are still broadly used in the field of modern medicine [45].

Table 1. Medicinal plants which laid the foundation of drug discovery

\begin{tabular}{|c|c|c|}
\hline Drug & Plant & Activity \\
\hline Morphine & Paparer somniferum & powerful pain reliever and narcortic \\
\hline Quinine & Cinchona sp. & anti-malarial \\
\hline Taxol & Tarus brevifollis & Anticancerous \\
\hline Vincristine & Catharennthus rosesess & Anticancerous \\
\hline Serpentine & Raluwolfia serpentia & hypertension \\
\hline
\end{tabular}

Source: [45-46]

Other than the biologically active natural products derived from medicinal plants stated above, a great number of natural products derived from medicinal plants have also served as "lead compounds" to design, synthesize and develop novel drug compounds [47]. In this perspective, to prepare so called "semi-synthetic drugs" some natural products derived from plants have been modified marginally to make them more effective or less toxic [39]. In 1953 aspirin was developed as an example to such type of tactic with the help of structural modification of salicylic acid that was observed as an active constituent in many medicinal plants known for having painrelieving effects [47]. Guanidine-type of alkaloid, galegine in G. officinalis has blood glucose lowering property and because the alkaloid was found to be very toxic for human use therefore, a number of structural analogs of this alkaloid were made and tested clinically. These efforts resulted in the development and marketing of metformin which is an effective antidiabetic drug [45].

\section{Bioactive compounds from medicinal plants}

The extracts of several medicinal plants are very effective against microbial as well as parasitic infections [17]. For example, several groups of antifungal proteins like glucanase, chitinase and proteins which are of low molecular weight and non-enzymatic in nature are present in the seeds of many medicinal plants and these proteins are being used for the protection of a developing embryo from many infections [18]. Shoemaker et al. [48] has reported that there are over 400,000 species of plants on earth which have a huge reservoir of bioactive compounds, but only a small percentage of these have been examined in the research studies. When the bioactive compounds from traditional medicinal plants were investigated through screening programs, it resulted that these compounds possessed a considerable number of therapeutic properties. As a consequence a number of antitumoral drugs [49] and antifungal agents [50] are available for clinical uses and have been derived from plants. In another study [51], it has also been reported that plants are an important and continuous source of anticancer agents. During last 10-15 years, the fungal pathogens have gained resistance against presently engaged antifungal drugs and the adverse reactions or toxicity of the anti-infective. Due to this reason the importance of medicinal plants has been increased because they possess antimicrobial and antifungal activities [52].

Several epidemiological studies have shown that certain dietary elements play an important role in the prevention as well as in the etiology of different types of human cancers. The people who use plant-derived foods in great amounts such as vegetables, fruits and soybeans have less chances of cancer [53]. Although documentation was limited but it was observed experimentally that the preparations of certain plants may cure many diseases [54]. Stem parts of Euphorbia candelabrum plant has been used against Newcastle Disease (ND) in poultry while the leaves of Iboza multiflora in combination with Capsicum annuum fruits have been used to cure ND as well [54]. Mtambo et al. [55] reported that in a local preparation in Northern Tanzania consisting of three plants, namely Capsicum frutescens, Citrus limon and Opuntia vulgaris possess a therapeutic efficiency against ND in commercial chickens. In parasites and pathogenic microbes, the development of multi-drug resistance and for systemic mycoses the nonavailability of safe antifungal drugs has forced the researchers to look for new antimicrobial substances from some other sources, including plants. The medicinal plants which have been used traditionally produce a wide range of compounds with known therapeutic values [56]. For the production of new antimicrobial drugs, those substances are considered the most which have little toxicity to host cells and can inhibit pathogens. The antimicrobial properties of medicinal plants from South Asia have been increasingly reported [57-58]. In the local traditional systems of medicines, most of these medicinal plants have been used to cure different ailments including infectious diseases [56]. For instance, Terminalia arjuna bark has been extensively used for a variety of purposes and particularly, the bark has been effectively used in cardiovascular therapy [59]. Similarly, Andrographis lineate has been used for the treatment of snake bites [60].

\section{Herbal medicines today}

Various methods have been used to obtain compounds for drug discovery including isolation and purification of active compounds from medicinal plants and other natural sources, combinatorial chemistry, synthetic chemistry and bioinformatics approaches (e.g. molecular modeling) [61]. Although the pharmaceutical companies and funding organizations are getting interested towards combinatorial chemistry, molecular modeling and other synthetic chemistry techniques but natural products and particularly medicinal plants remain an important source of new drugs, new chemical entities (NCEs) and new drug leads [16].

Mostly the plant medicines have been used in their crude forms before nineteenth century and administered as infusions (herbal teas), 
decoctions (boiled extracts of bark and root), tinctures (alcoholic extracts) and syrups [62]. Plants have also been applied externally as herbal washes and ointments (essential oils, poultices and balms) [46]. Researchers in developing countries who work on medicinal plants often experience a comprehensive exercise for the learning of names, uses and preparations of native plants [63], and in a number of marketplaces of villages of such countries the medicinal plants are being sold along with vegetables and other goods. The World Health Organization (WHO) has also recognized that in developing countries the agenda for effective health can never be accomplished by western medicine alone therefore it should be supplemented by other medicines which also include traditional herbal medicines of these countries [64]. It has also urged and advised accordingly to utilize the resources of their medicinal plants and other systems of traditional medicines to accomplish primary healthcare goal. It is reported for developed countries that the patients of chronic diseases are turning towards herbal treatments as alternatives to modern synthetic drugs [65]. In developed countries this interest in the use of herbal medicines is believed to be motivated by several factors which include:

i. The effectiveness of herbal medicines: Medicinal plants are believed to be effective, gentle and most of the time specific in their function to organs or systems of human body, and the belief that herbal medicines can be used to treat certain diseases where conventional medicine fails [44].

ii. Side effects of synthetic drugs: Although synthetic or chemical drugs as compared to herbal medicines can have greater or quicker effects but they possess many adverse effects and risks. Herbal medicines are believed to be devoid of these adverse effects because millions of people around the world have been using herbal medicines against many diseases for thousands of years [66].

iii. Synthetic drugs are highly costly: Herbal medicines are generally less expensive as compared to synthetic ones.

Medicinal plants are continuously contributing to modern prescription drugs considerably by providing principal constituents which can be used to synthesize new drugs.

From medicinal plants the search and use of drugs and dietary supplements have been hastened in the recent past. Biochemists, microbiologists, botanists, pharmacologists and chemists of natural products around the world are engaged to investigate medicinal plants for geting more and more phytochemicals and lead compounds which could be developed to treat different diseases.

\section{Herbal medicine in Pakistan}

In developed countries although the direct use of medicinal plant extracts continued to decrease in the late nineteenth and early twentieth centuries but in many parts of the world the medicinal plants are still playing a very important role in healthcare systems [67]. According to World Health Organization [68] for primary healthcare needs, $60 \%$ of world's population is dependant on traditional medicines and $80 \%$ population of developing countries is depending almost completely on traditional plants to get herbal medicines [69]. To the present day, the long tradition of herbal medicine continues in China, India, Pakistan and many other African and South American countries [70-71]. Pakistan is very rich in botanical wealth and diversity of plants resources because it has different climatic and edaphic factors. Only a small percentage of plants have been investigated biochemically [22] and now an extraordinary importance and popularity is being received by green pharmaceuticals [72].

In Pakistan, the major research activities on medicinal plants are on the level of documentation and the research works are being conducted mostly in universities as ethnobotanical listing of resources. There are a number of research institutes in Pakistan which are involved in survey to various kinds of analytical studies. In Table 2, a list of some known organizations is given which are involved in medicinal plants research. The knowledge of local communities of the country about traditional uses of medicinal plants occurring in their areas are centuries old which has been transferred from generation to generation. These indigenous plants are used for the treatment of almost any kind of disease including headache, stomachic, cut and wound [73]. For the extraction of various types of active constituents, some of the important plants are commercially harvested.

Table 2. Major organizations of Pakistan involved in medicinal plants research

\begin{tabular}{|c|c|c|c|}
\hline Name of Department & Organization & Interest Area & \begin{tabular}{|l} 
Initiated \\
since
\end{tabular} \\
\hline $\begin{array}{l}\text { Dept. of Botany, Pharmacy; } \\
\text { Chemistry and Pak. Forest Inst }\end{array}$ & Peshawar University & $\begin{array}{l}\text { Documentation; analytical } \\
\text { work }\end{array}$ & 1950's \\
\hline ICCS, HEJ Inst:; Botany Dept. & Karachi University & Chemical analysis & 1960's \\
\hline Handard Laboratories & Handard, Karachi & Herbal Medicine & 1960's \\
\hline Dept. of Botany and Biochemistry & Baluchistan Univ, Quetta & $\begin{array}{l}\text { Documentation and } \\
\text { Antalysis }\end{array}$ & 1970 's \\
\hline Qarshi Research Int & Qaarshi Industries (Pvt) Ltd. & $\begin{array}{l}\text { Herbal Medicine; Bot. } \\
\text { Garden }\end{array}$ & 1980 's \\
\hline $\begin{array}{l}\text { Dept. Plant Sciences and } \\
\text { Chemistry }\end{array}$ & Quaid-j-Azam University & $\begin{array}{l}\text { Zthrnobotanical studies and } \\
\text { Chemical analysis }\end{array}$ & 1980 's \\
\hline $\begin{array}{l}\text { Department of Biological and } \\
\text { Biomedical Sciences }\end{array}$ & Agha Khan University, Karachi & Pharmacognocy & 1990's \\
\hline National Agric. Res. Center & $\begin{array}{l}\text { Pak. Agric. Res. Council, } \\
\text { Islamabad }\end{array}$ & $\begin{array}{l}\text { Cultivation and } \\
\text { Documentation }\end{array}$ & 1990's \\
\hline Dept. of Botanly and Chemistry & Kohat University of Sci. and Tech. & $\begin{array}{l}\text { Documentation; analytical } \\
\text { work }\end{array}$ & 2004 \\
\hline Dept. of Biochemistry & University of Agriculture, & Analytical work and & 2009 \\
\hline
\end{tabular}

\section{Medicinal plants from Northern areas of Pakistan}

The northern most tracts of Pakistan cover an area of 72,486 sq. km, border the Indian-administered Jammu and Kashmir to the east, Central Asia and Afghanistan through the Wakhan Corridor to the west, Chinese province of Xinjiang to the north and Pakistan-administered Azad Jammu and Kashmir to the south. The Northern areas are divided into six districts. Gilgit region has four districts which include Astore, Ghizer, Diamer and Gilgit. Baltistan region has two districts which include Ghangche and Skardu (Fig 1). Being a multidisciplinary, ethnobotany has not been given much importance in Northern areas of Pakistan although they have ample scope in this field. However, recently these studies have started to gain momentum [74].

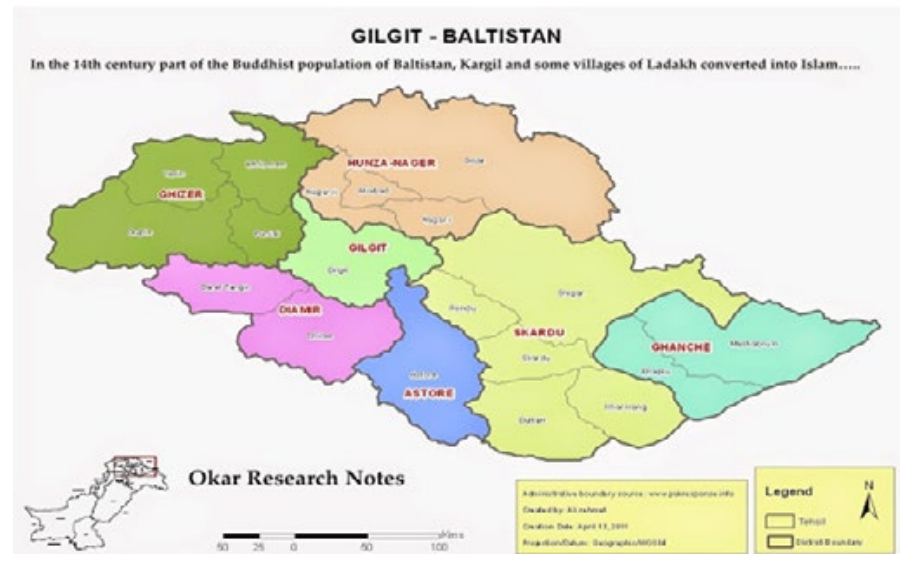

Fig 1. Map of Northern areas of Pakistan (internet source)

A great treasure of medicinal plants is present in northern areas of Pakistan. Leporatti and Lattanzi [75] studied 27 medicinal plants ethenobotanically in Makran and discussed their traditional medicinal uses. Goodman and Ghafoor [76] conducted ethenobotanical study in Balochistan province. It is the region where a heterogeneous cultural group known as Baloch lives. They collected information about 114 plant species used by nomads and village dwellers. Shinwari [77] focused on information regarding traditional uses of plants of Kaghan valley. Dastagir [78] reported the medicinal plants of Mai Dhani Hill, Muzaffarabad (AK). Bukhari [79] reported that as many as 69 plant species are used as crude drugs by the local people and folk lore for treating various diseases in National Park Machayara Muzaffarabad (AK). Khan [80] reported phytosociological study in Babusar valley and recorded five plant communities in Babusar valley, district Diamer. He also described the vegetation type, range management and medicinal plants of the area. Rasool [81] studied the medicinal plants conservation status of Northern areas and recorded 60 medicinal plants from different locations of Northern areas. Gorsi and Shahzad [82] reported the medicinal uses of plants by the local community in Dhir Kot, district Bagh (AK). Local people collect 
medicinal plants for use as home remedies at large. Information about the collection, quantities and uses of the plants are badly needed to be communicated.

Importance has always been given to therapeutic plants as a mode of treatment for different diseases in local cultures. Plants have also played a vital role for the discovery of modern day medicines with novel chemical compounds [83]. Although the effectiveness of medicinal plants is often accounted for curative purposes in terms of organic constituents they possess such as vitamins, oils and glycosides but it is also an established fact now that the over dose or prolonged intake of some medicinal plants would lead to chronic accumulation of various elements that cause different health problems [84]. Traditional uses of some commonly used medicinal plants by local people of Northern areas are given in Table 3.

Table 3. Some medicinal plants from Northern areas with their traditional uses

\begin{tabular}{|c|c|c|c|c|}
\hline S.\# & Plant & Local name & Parts used & Local use/ effective against \\
\hline 1 & Amaranthus viridis $\mathrm{L}$. & Chalwai & $\begin{array}{l}\text { Shoots and } \\
\text { leaves }\end{array}$ & Cough and asthma \\
\hline 2 & Coriandrum sativum $\mathrm{L}$. & Dhanial & Fruit & Stomachache \\
\hline 3 & Foeniculum vulgare & Kaga Velanay & Finit & Dysuria and as laxative \\
\hline 4 & Artimisia vulgaris $\mathrm{L}$. & Tarkha & Young shoots & $\begin{array}{l}\text { Antispasmodic } \\
\text { and stomachache }\end{array}$ \\
\hline 5 & Cichorium intvbus $\mathrm{L}$. & Han & Root & Aundice and fever \\
\hline 6 & Taxaraculum officinale & Ziarr Gulay & Leaves and roots & Disorders of kidney and liver \\
\hline 7 & Berbiris lycium & Kwalay & Root & $\begin{array}{l}\text { Rephorlogical complaints and } \\
\text { jaundice. }\end{array}$ \\
\hline 8 & $\begin{array}{l}\text { Capesella bursa pastoris } \\
\text { L. }\end{array}$ & Bambesa & Leaves and stem & Diarrahea \\
\hline 9 & Nassurtium officinale & Talmira & Young shoots & Constipation and stomaclache \\
\hline 10 & Sarcacoca saligna & Ledant & Herb & Muscular pains and ricumatism \\
\hline 11 & Camnabis satine $\mathrm{L}$. & Bhang & $\begin{array}{l}\text { Shoots and } \\
\text { leaves }\end{array}$ & $\begin{array}{l}\text { Wounds healing and anodyne (Pain } \\
\text { relieving agent) }\end{array}$ \\
\hline $\begin{array}{l}12 \\
13\end{array}$ & $\begin{array}{l}\text { Vibernum grandifforing } \\
\text { Silene rulgaris }\end{array}$ & $\begin{array}{l}\text { Ghaz mera (Asos) } \\
\text { Bashlka }\end{array}$ & $\begin{array}{l}\text { Fruit } \\
\text { Leaves and }\end{array}$ & $\begin{array}{l}\text { Stomach disorders } \\
\text { Stomachacbe and as emollient }\end{array}$ \\
\hline 14 & Stellarium medlia & Oulaki & Whole plant & As purgalive \\
\hline 15 & Cuscuta reflexa Romb. & Niladoria & Wholk plant & Diabctes \\
\hline 16 & Diospgrus Lotus L. & Tor Amlook & Fruit & $\begin{array}{l}\text { Dysentery and } \\
\text { constipation }\end{array}$ \\
\hline 18 & $\begin{array}{l}\text { Eleagnus unbellate } \\
\text { Euphorbra wallichn }\end{array}$ & $\begin{array}{l}\text { Ghanam ranga } \\
\text { Shangla }\end{array}$ & $\begin{array}{l}\text { Flowers heads } \\
\text { Shoots }\end{array}$ & $\begin{array}{l}\text { Heart problem, cough and chest pain } \\
\text { Bowl complains and also used for } \\
\text { the removal ot ning worms in } \\
\text { childrea }\end{array}$ \\
\hline 19 & Fevmaria intica & Paprra & Whole plant & $\begin{array}{l}\text { Jaundice and also uscd as blood } \\
\text { purifier }\end{array}$ \\
\hline 20 & Germitum wallichimum & Srazela & Rhizome & $\begin{array}{l}\text { Curing of kidney diseases, cough } \\
\text { and fever }\end{array}$ \\
\hline
\end{tabular}

\section{Medicinal plants from Cholistan desert of Pakistan}

In the southeastern part of the Indus plain from eastern Bahawalpur to southern Thar Parkar region there is a typical desert which is an extension of Thar Desert present between Pakistan and India. The desert is separated by dry bed of the river Ghaggar from central irrigated zone of plains in Bahawalpur and eastern Nara canal in Sindh. In Bahawalpur the desert in known as Cholistan or Rohi and in Sindh it is called as Thar or Pat desert. The surface of Cholistan desert is a wild maze of sand dunes and ridges. Along the south border of Punjab province Cholistan desert is stretched (Fig 2) and it a part of world's seventh largest desert also known as the Great Desert [86] which lies at an altidue of $112 \mathrm{~m}$ above the sea level [87]. Comprising an area in total about $25,000 \mathrm{~km} 2$ Cholistan desert lies between $27^{\circ} 42^{\prime}$ and 29 $45^{\prime}$ North and 69 $52^{\prime}$ and 75을 24' East [88].

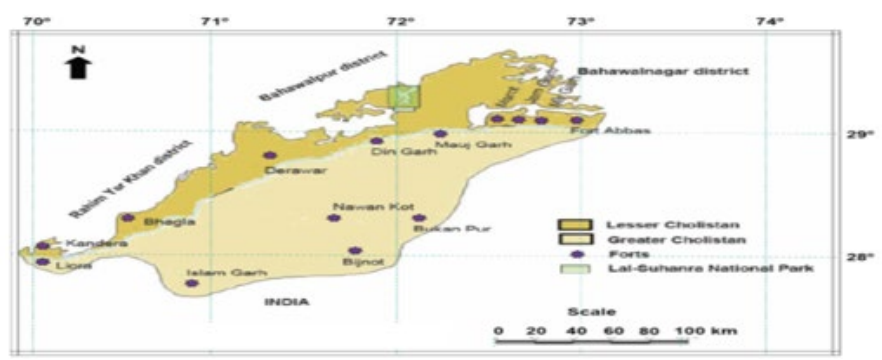

Fig 2. Map of Cholistan desert of Pakistan (Source: [89])

Medicinal plants from neighboring countries that share habitats similar to Cholistan especially from India have been explored for their medicinal properties and traditional uses. Although, a great number of medicinal plants from Cholistan desert have been frequently used the local people but unfortunately, the active constituents from these plants with their medicinal properties have still not documented [89]. Neurada procumbens is one of the most conspicuous examples and a great deal of mistreatment of this important medicinal plant has made its indigenous status endangered to a critical level.

The treasure of medicinal plants in Pakistan has never been preserved which causes loss of very important medicinal plants. Therefore, there is a need to take steps for the conservation of these important medicinal plants. In addition to Government of Pakistan, local people who are working on medicinal plants should also follow guidelines for the collection and harvesting of these important medicinal plants. N. procumbens has been extensively used as a strong stimulant and strong tonic against weakness and impotency besides as a cooling agent [90]. The serious threat to the diversity of medicinal plants in Cholistan is from habitat degradation because of agricultural practices. The farmers cultivate their desirable crops and destroy or ignore other important plant species. There is an urgent need for the conservation of medicinal plants in Cholistan by sustaining natural habitat. The existing knowledge and documentation of medicinally important plants should be promoted. The local communities of this region also exploit these plant species for different purposes such as food, fodder and construction. One such example is of Prosopis cineraria whose seeds and fruits are used extensively in various dishes [91]. The herbal aqueous extract of Cymbopogon jwarancusa is used by the people of Cholistan in summer for relaxing and reducing thirst. Calotropis procera is another important medicinal plant whose each and every part is used by the local communities to cure various diseases and some part of this plant have other applications such as fruit floss are used in pillows and cushions for stuffing [92].

There are a great number of other examples of local medicinal plants from Cholistan desert whose applications along with their chemical constituents are not yet reported. Although there is a big list of medicinal plants which are traditionally used by the local people of Cholistan desert but applications of some commonly used medicinal plants by these people are given in table 4. Local names of these medicinal plants along with parts which are used to cure different diseases are also given in the table.

Table 4. Some medicinal plants from Cholistan desert with their traditional uses

\begin{tabular}{|c|c|c|c|c|}
\hline S.\# & Plant & Local name & Parts used & Local use/ effective against \\
\hline 1 & Achreranthes aspera & Ubat Kandri & Roots & \begin{tabular}{|l|l|} 
Asthma, cough, pneumonial \\
joint pain
\end{tabular} \\
\hline 2 & Aerva javanica & Booln & Whole plant & \begin{tabular}{|l|} 
Toothache \\
\end{tabular} \\
\hline 3 & Amaranthus virdis & Mariro & Whole plant & $\begin{array}{l}\text { Constipation, gall bladder } \\
\text { and kidney stones }\end{array}$ \\
\hline 4 & Aristolochia bracteolata & Kabar & Leaves & Ulcer, eczema, dermatitis \\
\hline 5 & senna italica & Ghorawal & Leaflets & Backache, \\
\hline 6 & Chenopodium album $L$. & Chill & Whole plant & Constipation \\
\hline 7 & Citrullus colocynthis & Trooh & Roots, Fruits & Toothache, Constipation \\
\hline 8 & Cleome brachicarpa & $\begin{array}{l}\text { Dhanar } \\
\text { Khathuri }\end{array}$ & Whole plant & Joint pain and inflammation \\
\hline 9 & Cleome viscosa $L$. & Kinni Buti & Whole plant & Ear infection, pain and deafness \\
\hline 10 & Convolvulus arvensis $L_{\text {. }}$ & Naaro & Leaves & Boils and inflanmation \\
\hline 11 & Desmostachya bipimata & Drabh & Roots & Carbuncle \\
\hline 12 & Digera muricata & Lulur & Whole plant & Constipation \\
\hline 13 & Fumaria indica & Shahatro & Whole plant & skin diseases \\
\hline 14 & Gmandropsis gynandra & Kinro & Leaves & Fever, boils, earache, otalgia \\
\hline 15 & Kicktia ramosissima & Wal & Whole plant & Diabetes \\
\hline
\end{tabular}




\begin{tabular}{|c|c|c|c|c|}
\hline 16 & Leucas aspera & Goomi Buti & Whole plant & Pain and inflammation \\
\hline 17 & Newrada procumbens & Kotak & Fruits & Sexual debility \\
\hline 18 & Phyla nodiflora & Bukkan & Whole plant & Micturition, dysuria \\
\hline 19 & Tribullus terrestris $L$. & Baklhro & Fruits & $\begin{array}{l}\text { Urinary calculi, spermatorrhoea, } \\
\text { general debility }\end{array}$ \\
\hline 20 & Zelva petandra & $\begin{array}{l}\text { Wasanhl } \\
\text { Waaho }\end{array}$ & Roots & Influenza, phlegmatic cough \\
\hline
\end{tabular}

\section{Secondary plant metabolites with medicinal properties}

The pharmacological and medicinal properties of medicinal plants are often attributed to the presence of so called secondary plant metabolites [116]. Unlike the presence of universal macromolecules of primary metabolism (e.g. monosaccharides, polysaccharides, proteins, nucleic acids, lipids and amino acids) in all plants, the secondary metabolites which have medicinal properties are observed only in a few species of plants [117]. Against herbivores and pathogens some of these secondary metabolites play a role as defensive compounds while others function in attracting pollinators and fruit dispersers, in reducing the growth of nearby competing plants, in mechanical support for plants or in absorbing harmful ultraviolet radiation [118]. Polysaccharides, waxes and fatty acids, terpenoids, phenolics (simple phenolics and flavonoids), alkaloids and glycosides and their derivatives are plant secondary metabolites which have reported medicinal properties but not limited to these compounds only. Some of these plants secondary metabolites are discussed here briefly:

Table 5. Ethnopharmacological applications of some medicinal plants along with their phytochemicals

\begin{tabular}{|c|c|c|c|c|c|}
\hline $\begin{array}{l}\text { Sr. } \\
\text { No. }\end{array}$ & Plant/Loeal name & Parts used & \begin{tabular}{|l}
$\begin{array}{l}\text { Preparation and } \\
\text { application }\end{array}$ \\
\end{tabular} & Investigation & Phustochem clals found \\
\hline 1 & 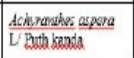 & Root & $\begin{array}{l}\text { Root infusion is } \\
\text { tolisen orlly }\end{array}$ & 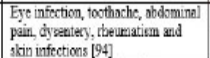 & Allaline ash containing potash, sapoin [95] \\
\hline 2 & delingan coplith $\mathrm{L}$ & Aenial pats & $\begin{array}{l}\text { Desoction of earial } \\
\text { prts is taken crally. }\end{array}$ & 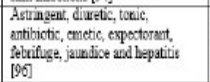 & 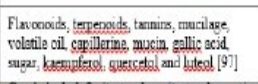 \\
\hline 3 & $\begin{array}{l}\text { Aluge bracieasa' } \\
\text { Path boot }\end{array}$ & Areial pats & $\begin{array}{l}\text { Juice of firesh zerial } \\
\text { purts is taken orilly } \\
\text { before brealffast. }\end{array}$ & 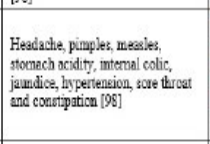 & 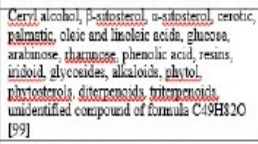 \\
\hline 4 & Alfien sez L B biar & Eulb & $\begin{array}{l}\text { Slightly wanu paste } \\
\text { of bull in musterd } \\
\text { oil is tighteaing ores } \\
\text { boils and uats for a } \\
\text { rigit. }\end{array}$ & Gastic trobble, arti-dieactic [100] & 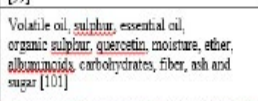 \\
\hline s & 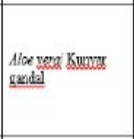 & Leas püp & $\begin{array}{l}\text { Freesh puip is laycered } \\
\text { for a day. }\end{array}$ & 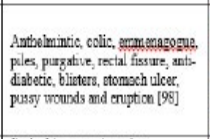 & 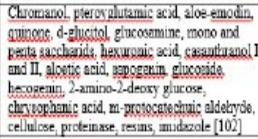 \\
\hline 6 & 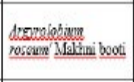 & Leaver & 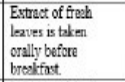 & 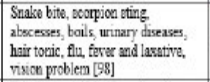 & 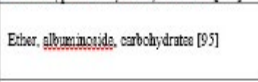 \\
\hline$?$ & $\begin{array}{l}\text { Rezezzis greum } \\
\text { Simbal }\end{array}$ & Burk & 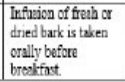 & 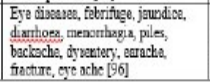 & 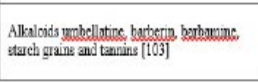 \\
\hline
\end{tabular}

\begin{tabular}{|c|c|c|c|c|c|}
\hline 8 & 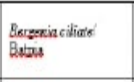 & shism & 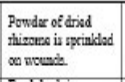 & 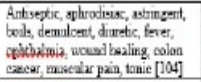 & 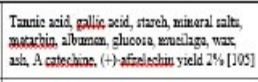 \\
\hline 9 & $\begin{array}{l}\text { Bambarcceiba L Dus } \\
\text { swabut }\end{array}$ & Butk & 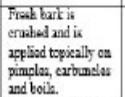 & $\begin{array}{l}\text { Alkerative, stringent, restorative, } \\
\text { troxic }[106]\end{array}$ & Drying oli, taxicic and palis seide [107] \\
\hline 10 & 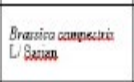 & Sodd & 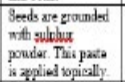 & 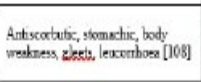 & 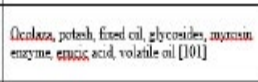 \\
\hline 11 & 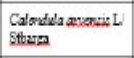 & Loners & 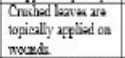 & $\begin{array}{l}\text { Ant.pasaodic and cenjunctivitas } \\
\text { [22] }\end{array}$ & 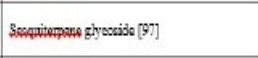 \\
\hline 12 & $\begin{array}{l}\text { Calatansispencosed } \\
\text { Ask }\end{array}$ & Later: & 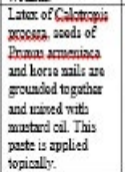 & $\begin{array}{l}\text { Pwgzativa, akin infoction } \\
\text { expostorat, wabshinitic, } \\
\text { disphoretic [109] }\end{array}$ & 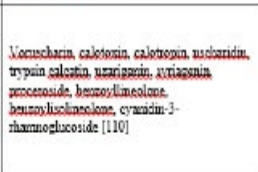 \\
\hline 13 & $\begin{array}{l}\text { Canubies sartiv I/ } \\
\text { Bhang }\end{array}$ & Lexies & 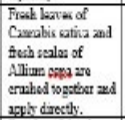 & 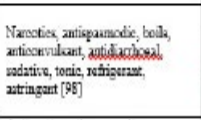 & 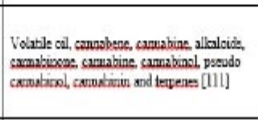 \\
\hline 14 & 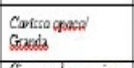 & Root & 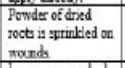 & 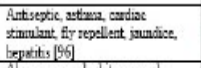 & 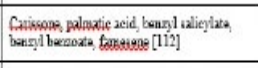 \\
\hline 15 & 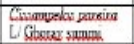 & Leares & 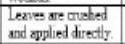 & 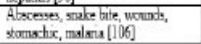 & 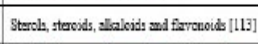 \\
\hline 16 & 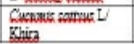 & Fruit & 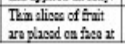 & 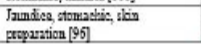 & 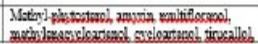 \\
\hline
\end{tabular}

\section{i). Carbohydrates and related compounds}

Fibre, cellulose and its derivatives, dextrins, fructans, pectins, starch and its derivatives, mucillages (uronic acid containing polymers) and gums are carbohydrates and related compounds derived from plants [119]. Carbohydrates and related compounds in addition to their use in pharmaceutical industry as bulking agents have also been shown to have immune-modulatory, hypoglycaemic, anticoagulant (e.g. heparin), antitumor and antiviral activities [46].

\section{ii). Alkaloids}

Alkaloids contain nitrogen in a heterocyclic ring are organic bases and many of them have pronounced pharmacological activities [120]. On the basis of either their basic ring system (e.g. atropine, quinoline, indole, isoquinoline, piperdine alkaloids or imidazole) or plant sources (e.g. opium, vinca, belladonna, ergot alkaloids or cinchona) or pharmacological properties (e.g. analgesic, anti-malarial alkaloids or stimulant) alkaloids can be classified into several groups [116]. Mostly, alkaloids are strongly bitter in taste and are very toxic, for these reasons they are used by plants to defend them against herbivores, microbial pathogens and invertebrate pests attacks [119]. Heinrich et al. [116] reported that several medicinal plants which contain alkaloids have been used by the early man as pain relievers and as recreational purposes or in some religious ceremonies to achieve a psychological state in which they could communicate with their ancestors or god. Structure of reserpine is given in fig 3 as an example of alkaloids. Reserpine was derived from Vinca rosea and Rauwolfia serpentine and it reduces the production of neurotransmitters which causes hypotension and sedation by interfering membrane of synaptic vesicles [121].

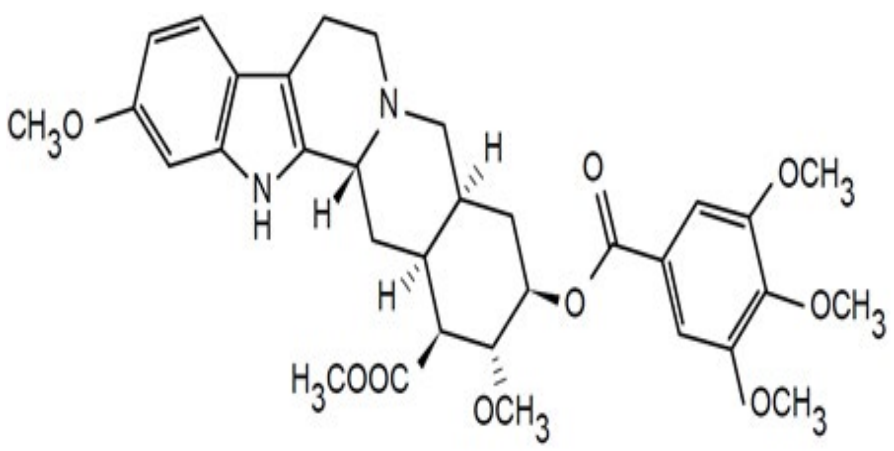

Fig 3. Structure of reserpine (an alkaloid) (Adopted from: [45]

\begin{tabular}{|c|c|c|c|c|c|}
\hline & & & might & & 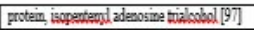 \\
\hline 17 & 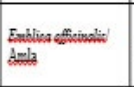 & Learies & $\begin{array}{l}\text { Lasves are erubed } \\
\text { and directy applied }\end{array}$ & 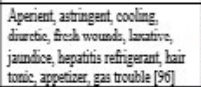 & 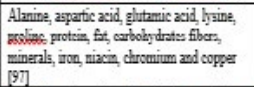 \\
\hline 18 & $\begin{array}{l}\text { Onalit censiculasta L } \\
\text { Jandsa }\end{array}$ & Leaves & 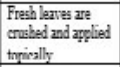 & 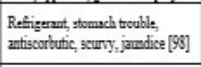 & 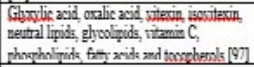 \\
\hline 19 & 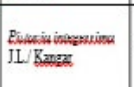 & Bark & $\begin{array}{l}\text { Del is uubbed and } \\
\text { topically appliad. }\end{array}$ & 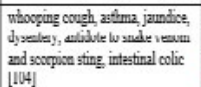 & 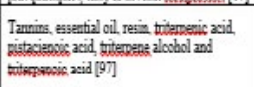 \\
\hline 20 & Pha chinocitiv Iixter & Frit & 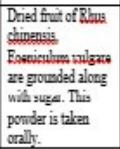 & Jamines, bepatitis [96] & 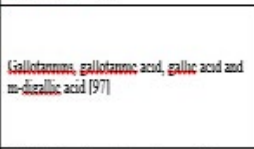 \\
\hline 21 & 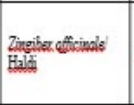 & Blivenen & $\begin{array}{l}\text { Pouder is gprinled } \\
\text { on woumbs }\end{array}$ & $\begin{array}{l}\text { Indigestion, lahour pain uticanial } \\
\text { [114] }\end{array}$ & 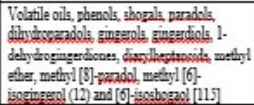 \\
\hline
\end{tabular}

\section{iii). Phenolics}

Another class of plant secondary metabolites are phenolics which are characterized by the presence of one or more hydroxyl $(-\mathrm{OH})$ groups attached to an aromatic ring either benzene or some other complex aromatic ring structure [116]. Phenolics plant secondary metabolites on the basis of their structure can be classified into two broad classes, flavonoid and non-flavonoids phenolic compounds and they are responsible for the development of different colors in plants and play a role in pollination also they protect plants from UV radiation and pathogens $[116,119]$. A three ring structure with two aromatic centers (ring A and B) and a central oxygenated heterocyclic ring $(\mathrm{C})$ are contained by flavonoids which are a large and complex group of phenolics compounds [122] (Fig 4). Flavonoids are known to be present in garlic and they have been found effective in reducing atherosclerosis, coronary thrombosis, cholesterol level and many other serious as well as fatal ailments [121]. 


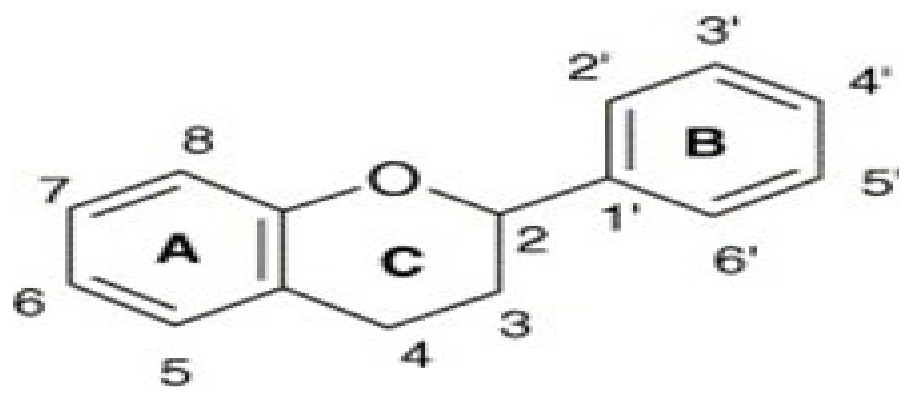

Fig 4. Basic structure of flavonoids (Adopted from: [123])

On the other hand simple phenols (e.g. euginol, hydroquinone, catechol, phloroglucinol and p-anisaldehyde) [124], the C6-C3 phenyl propanoids and their derivatives (caffeic acid, cinnamic acid, ferulic acid myristicin and synapyl alcohol), the C6-C1 benzoic acids (gallic acid, vannilic acid and protocatechic acid), coumarins (warfarin, scopoletin and dicoumarol), hydrozable tannis (gallotannins and ellagitannins) and lignans and related compounds all are included in non-flavonoid phenolic compounds.

\section{iv). Terpenoids}

The largest group of plant secondary metabolites is terpenoids which are also known as isoprenoids [119]. Terpenoids are classified on the basis of isoprene units into monoterpenes (C10), sesquiterpenes (C15), diterpenes (C20), triterpenes (C30) and tetraterpenes (C40) [46,116]. They play different roles in plants such as in defense, thermotolerance, wound scaling and pollination of seed crops. Terpenoids also give flavors to fruits, fragrance to flowers and also responsible for the quality of agricultural products [116]. Structure of bisabolol is given in fig 5 representing Sesquiterpenes (C15). Bisabolol is used as an anti-bacterial, antifungal, antimalarial and mulluscicidal drug [125] and isolated from different plant sources such as Salvia stenophylla [126] and Plinia cerrocampanensis [127].

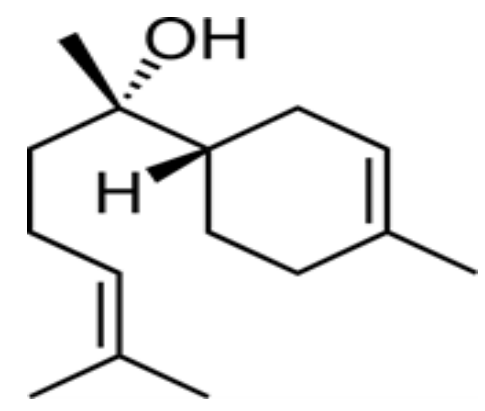

Fig 5. Structure of bisabolol (Adopted from: [125])

\section{v). Glycosides}

Glycosides are plant secondary metabolites which are made up of two components including glycone (a carbohydrate component) and aglycone (a non-carbohydrate component). The former component usually consists of one or more glucose units and the latter component may be any one of the plant secondary metabolites from alkaloids, phenolics or terpenoids $[46,116]$. Anthraquinone glycosides, steroidal (cardiac) glycosides and coumarin glycosides are medically important glycosides but the medicinal importance is not limited to these glycosides only. Structure of aloesin is shown in fig 6 that is an example of glycoside. Aloesin has been isolated from Aloe vera and reported for antioxidant activity, free radical scavenging and anti-inflammatory effects [128].<smiles>CC(=O)Cc1cc(=O)c2c(C)cc(O)c([C@@H]3O[C@H](CO)[C@@H](O)[C@H](O)[C@H]3O)c2o1</smiles>

Fig 6. Structure of aloesin (a glycoside) (Adopted from: [129])

\section{Bioactive compounds and defense mechanisms in plants}

Bioactive compounds (also known as defense bioactive compounds) are a wide variety of chemically diverse compounds produced by plants through complex mechanisms to respond the attacks of insect herbivores and microbial pathogens. Bioactive compounds from plants have been widely used in cosmetic, food and pharmaceutical industries [130]. Microorganisms are causing diseases in a huge number of plant hosts and are responsible for big losses in economical crops and also preventing valuable food distribution worldwide [131-132]. The plants which are continuously exposed to a large number of pathogens are being attacked in both chemical and mechanical ways by these pathogens [133]. It has also been found that against these pathogen attacks, plants show both inducible and constitutive defenses [134]. And these defenses are due to the transcriptional regulation of genes which plays a primary role in response against the pathogen infections in plants [135]. The pathogen attacks induce a number of defense-related and pathogenesis related (PR) genes in plants and these genes are regulated transciptionally through different signal transduction pathways which are mediated by ethylene [136], salicylic acid [137], jasmonic acid [138] and probably hydrogen peroxide [139]. A wide range of mechanisms are involved in plants for defense against invading pathogens. These include the induction of those genes which encode pathogenesis-related (PR) proteins, the hypersensitive response (HR) which is necessary for restricting the pathogens from spreading at the primary site of infection and the production of those enzymes which are involved in the production of phytoalexins. In addition, those which are related to tissue repair, oxidative stress protection and cell wall lignification [140].

Different active protective mechanisms and constitutive defense barriers which are accompanied by a variety of physical and biochemical changes are also involved in plants to play an important role in defense against different pathogens. Synthesis of a group of pathogenesis-related (PR) proteins which are host-encoded proteins is one of the most studied defense responses in plants. It has been suggested recently that thionins [141], plant defensins [142] and lipid transfer proteins [143] which are different groups of small, basic and cysteine-rich antimicrobial proteins they may play an important role in plant defense responses. In fact it has been found that some PR proteins have in vitro antifungal activity [144]. Similarly, Alexander et al. [145] has also reported that the genetically engineered and overexpressing PR proteins in plants have been found to be resistant against pathogen infections. Moreover, by the treatment of abiotic elicitors the PR proteins can also be induced in plant tissues. In addition to biotic elicitors, polyacrylic acid, benzoic acid, ethephon, 2,6-dichloroisonicotinic acid (INA), salicylic acid (SA), benzo $(1,2,3)$ thiadiazole-7-carbothioic S-methyl ester (BTH) and DL- $\beta$-amino-n-butyric acid (BABA) are also some renowned chemical inducers of PR proteins [145].

\section{i). Antimicrobial peptides (AMPs)}

Antimicrobial peptides (AMPs) provide resistance to plants against microbial infections and have been detected in many agricultural plant species [146]. In vitro strong antimicrobial activity of antimicrobial peptides and their localization in a wide range of plant tissues have indicated that they can play an important role for the protection of plants against pathogens. The role of these AMPs in plant protection is also supported by their high expression levels both systemically and locally during the attacks of different pathogens [147].

All these AMPs do have antimicrobial activity and they can be categorized into different types according to their structures and functions [146]. In different plants two well-known subclasses of these AMPs are found which are called as thionins and plant defensins [148]. Chitin-binding proteins [146], knottin-type peptides [149] and protease inhibitors [150] are some other AMPs which have also been isolated from medicinal plants and studied. Much attention has been given in recent years to the potential use of AMPs to design novel fungicides which should be environmentally friendly. To engineer genes of disease resistance in plants which can reduce the use of additional chemical fungicides, AMPs are also a possible source of these genes [151].

\section{ii). Anticancerous compounds}

Over the last century, the secondary metabolites of plants and their derivatives have acquired most new clinical applications as they are being applied to fight against cancers [16]. Drug discovery from medicinal plants for the treatment of different cancers has played a vital role. In a study [51] it was shown that from all the available anticancer drugs, , there were $40 \%$ natural products or their derivatives with another $8 \%$ were considered as a mimic of natural products. Many bioactive compounds comprising 
anticancerous activity have also been extracted and purified. The extracts of Pavetta crassipes showed potential toxicity against human cancer cells [152]. The leaves of Pavetta crassipes have also been reported to have indolomonoterpenic alkaloids, hydroxyl-elaeocarpidin and elaeocarpidin [153]. Balde et al. [154] described the potential of indolomonoterpinic alkaloids as effective compound to cure cancer, malaria and bacterial infections.

The anticancerours compounds from plants which are presently in clinical trials can be divided into four major classes of compounds: taxanes, vinca (or Catharanthus), camptothecins and epipodophyllotoxins. From Catharanthus roseus (L.) and Vinca rosea (L.) two anticancerous agents (i.e. vinblastine and vincristine) were isolated and for over 40 years both compounds were used clinically [155]. The vinca alkaloids and their different semi-synthetic derivatives inhibit mitosis by blocking metaphase through binding especially to tubulin which results in its depolymerization [156]. Tubulin binding was also showed by taxanes, including paclitaxel and derivatives without letting depolymerization or interference with tubulin assembly [157]. From the resin Podophyllum peltatum L. another anticancerous agent (i.e. podophyllotoxin) was isolated but in mice it was found toxic and therefore, its derivatives were prepared with etoposide that was the first clinically approved drug [158]. Camptothecin was obtained from Camptotheca acuminate but it showed intolerable myelosuppression originally [51] and when its action was found by selective inhibition of topoisomerase I, the interest in camptothecin was revived [159]. Various derivatives of all these four compounds have been produced and some of which are still in their clinical uses.

\section{Concluding remarks and future perspectives}

Natural products are the chemical compounds found in nature that usually has a pharmacological or biological activity for use in pharmaceutical drug discovery and drug design. Drugs of natural origin have been classified as original natural products, products derived semi-synthetically from natural products, or synthetic products based on natural product models. Collectively, plants produce a remarkably diverse array of over 100,000 low molecular-mass natural products, also known as secondary metabolites. Secondary metabolites are distinct from the components of intermediary (primary) metabolism in that they are generally nonessential for the basic metabolic processes of the plant. Many secondary metabolites have been isolated and characterized from a variety of natural sources, such as bacteria, fungi, and plants. They are of high interest and importance because they often exhibit a broad spectrum of biological activities. Phytochemicals are non-nutritive chemicals and responsible for medicinal properties of plants. Bases on the functions they perform in plants' metabolisms, phytochemicals are divided into two groups i.e. primary and secondary metabolites. Common carbohydrates, amino acids, proteins and chlorophylls belong to primary metabolites while alkaloids, terpenoids, flavonoids, glycosides, saponins, tannins, steroids etc are examples of plants secondary metabolites.

Keeping in view the importance of medicinal plants from Northern and desert areas of Pakistan, it is recommended that the indigenous people should be educated regarding the medicinal importance of plants from these areas and pre and post-harvest methods. It was observed in Northern areas of Pakistan that an important medicinal plant Ferula narthex has been destroyed up to $94 \%$ as the local people cut these medicinal plants above the root only to collect the latex. Therefore, the indigenous people from these areas should be trained regarding the cultivation of these important medicinal plants on commercial basis, their trade and marketing which would ultimately generate extra sources of income for these people and will also reduce pressure on the extraction of these valuable medicinal plants. Northern and desert areas of Pakistan are protected areas and all these destructive practices should be stopped immediately to ensure the survival of these valuable medicinal plants. Pakistan is a good example of plants biodiversity with a rich tradition of herbal remedies, and most of its population relies mainly on these medicinal plants for their healthcare issues. The medicinal plants may not be as useful as claimed or they may have more therapeutic properties than are known traditionally by indigenous people. Therefore, there is a need for proper scientific investigation to explore the exact medicinal potentials of these local plants.

\section{References}

[1] Malik, F., D. Hussain, A.S. Dil, A.Hannan, A.H. Gilani. 2005. Islamic republic of Pakistan. In: Ong, C.K., G. Bodeker, C. Grundy, G. Burford and K. Shein. (Eds.). WHO Global Atlas of Traditional, Complementary and Alternative Medicine (Map Volume). World Health Organization. Geneva. pp. 165-169 (Chapter22).

[2] Duraipandiyan, V., M. Ayyanar and S. Ignacimuthu. 2006. Antimicrobial activity of some ethnomedicinal plants used by Palyar tribe from Tamil
Nadu, India. BMC Complement. Altern. Med. 6: 35-41.

[3] Bolzani, V. da S., M. Valli, M. Pivatto, C. Viegas. 2012. Natural products from Brazilian biodiversity as a source of new models for medicinal chemistry. Pure Appl. Chem. 84: 1837-1846.

[4] Khalid, H., W.E. Abdalla, H. Abdelgadir, T. Opatz, T. Efferth. 2012. Gems from traditional north-African medicine: medicinal and aromatic plants from Sudan. Nat. Prod. Bioprospect. 2: 92-103.

[5] Li, J.W.H. and J.C. Vederas. 2009. Drug discovery and natural products: end of an era or an endless frontier? Science. 325: 161-165.

[6] Verma, S. and S. P. Singh. 2008. Current and future status of herbal medicines. Vet. World. 1(11): 347-350.

[7] Lewington, A. 1993. A review of the importation of medicinal plants and plant extracts into Europe. Cambridge, UK; TRAFFIC International. $37 \mathrm{pp}$.

[8] Sandhya, B., S. Thomas, W. Isabel, R. Shenbagarathai. 2006 Ethnomedicinal plants used by the Valaiyan community of Piranmalai Hills (Reserved Forest), Tamil Nadu, India. A pilot study. Afr. J. Traditional Complementary Altern. Med. 3(1): 101-114.

[9] Yaseen, G., M. Ahmad, S. Sultana, A. S. Alharrasi, J. Hussain, M. Zafar and S. Ur-Rehman. 2015. Ethnobotany of medicinal plants in the Thar desert (Sindh) of Pakistan. Journal of Ethnopharmacology. 163: 43-59.

[10] Jigna, P. and C.V. Sumitra. 2007. In vitro antimicrobial activity and phytochemical analysis of some Indian Medicinal plants. Turk. J. Biol. 31: 53-58.

[11] Hussain, F. 2007. Traditional resource evaluation of some plants of Mastuj, District Chitral, Pakistan. Pak. J. Bot. 39(2): 339-354.

[12] Lokhande, P.D., K.R. Gawai, K.M. Kodam, B.S. Kuchekar, A.R. Chabukswar and S.C. Jagdale. 2007. Antibacterial activity of isolated constituents and extracts of roots of Inula racemosa. Res. J. Medicinal Plant. 1: 7-12.

[13] Mahmood, A., S. Rashid and R.N. Malik. 2013a. Determination of toxic heavy metals in indigenous medicinal plants used in Rawalpindi and Islamabad cities, Pakistan. J. Ethnopharmacol.148: 158-164.

[14] Samuelsson, G., 2004. Drugs of Natural Origin: a Textbook of Pharmacognosy, 5th Swedish Pharmaceutical Press, Stockholm.

[15] Kinghorn, A.D., 2001. Pharmacognosy in the 21st century. J. Pharm. Pharmacol. 53(2): 135-148.

[16] Butler, M. S. 2004. The role of natural product chemistry in drug discovery. J. Nat. Prod. 67(12): 2141- 2153.

[17] Haider, Z., M.A. Sheikh, M. Shahid, A. Ahmad and S.M. Ali. 2001. Antihepatotoxic evaluation of Butea monbosperma against liver damage induced by Rifampicin and puracetamol in ckicks. J. Biochem. Mol. Biol. 35: 41-47.

[18] Wu, F., M. Yan, Y. Li, S. Chang, X. Song, Z. Zhou and W. Gong. 2003. cDNA cloning expression and mutagnesis of a PR-10 protein SPE-16 from the seeds of Pachyrrhizus erosus. Biochem. Biophys. 312:761-766.

[19] Mahmood, A., A. Mahmood, R.N. Malik and Z.K. Shinwari. 2013b. Indigenous knowledge of medicinal plants from Gujranwala district, Pakistan. J. Ethnopharmacol. 148: 714-723.

[20] Mustafa, G., Ahmed, S., Ahmed, N. and Jamil, A., 2016. Phytochemical and antibacterial activity of some unexplored medicinal plants of Cholistan desert. Pak. J. Bot, 48(5): 2057-2062.

[21] Saqib, Z., A. Mahmood,R.N. Malik, A. Mahmood, J.H. Syed and T. Ahmad. 2014. Indigenous knowledge of medicinal plants in Kotli Sattian, Rawalpindi district, Pakistan. J. Ethnopharmacol. 151: 820-828.

[22] Ahmad, M., M. A. Khan, M. Zafar and S. Sultana. 2007. Treatment of common ailments by plant-based remedies among the people of district Attock (Punjab) of Northern Pakistan. Afr. J. Tradit. Complement Altern. Med. 4: 112-120.

[23] Ibrar, M., F. Hussain and A. Sultan. 2007. Ethnobotanical studies on plant resources of Ranyal Hills, District Shangla, Pakistan. Pak. J. Bot. 39: 329-337.

[24] Ali, S.I. 2008. Significance of Flora with special reference to Pakistan. Pak. J. Bot. 40: 967-971.

[25] Ahmed, S.S. 2007. Medicinal wild plants from Lahore-Islamabad Motorway (M-2), Pakistan. Pak. J. Bot. 39(2): 355-375.

[26] Hall, R.D. 2006. Plant metabolomics: from holistic hope, to hype, to hot topic. New Phytol. 169: 453-468.

[27] Fiehn, O., J. Kopka, P. Dormann, T. Altmann, R.N. Trethewey and L. Willmitzer. 2000. Metabolite profiling for plant functional genomics. Nat. Biotechnol. 18: 1157-1161.

[28] Kim, H. and S.H. Park. 2009. Metabolic profiling and discrimination of two cacti cultivated in Korea using HPLC-ESI-MS and multivariate statistical analysis. J. Korean Soc. Appl. Bi. 52: 346-352.

[29] Pongsuwan, W., T. Bamba, K. Harada, T. Yonetani, A. Kobayashi and E. Fukusaki. 2008. High-throughput technique for comprehensive analysis of Japanese green tea quality assessment using ultra-performance liquid chromatography with time-of-flight mass spectrometry (UPLC/TOF MS). J. Agr. Food Chem. 56: 10705-10708. 
[30] Urbain, A., A. Marston, E. Marsden-Edwards and K. Hostettmann. 2009. Ultraperformance liquid chromatography/time-of-flight mass spectrometry as a chemotaxonomic tool for the analysis of Gentianaceae species. Phytochem. Anal. 20: 134-138.

[31] Tianniam, S., L. Tarachiwin, T. Bamba, A. Kobayashi and E. Fukusaki. 2008. Metabolic profiling of Angelica acutiloba roots utilizing gas chromatography-time-of-flight-mass spectrometry for quality assessment based on cultivation area and cultivar via multivariate pattern recognition. J. Biosci. Bioeng. 105: 655-659.

[32] Weckwerth. W. 2008. Integration of metabolomics and proteomics in molecular plant physiology - coping with the complexity by datadimensionality reduction. Physiol. Plant. 132: 176-189.

[33] Gustavsson, S.A., J. Samskog, K.E. Markides and B. Langstrom. 2001. Studies of signal suppression in liquid chromatography-electrospray ionization mass spectrometry using volatile ion-pairing reagents. J. Chromatogr. A. 937(1-2): 41-47.

[34] Plumb, R., J. Castro-Perez, J. Granger, I. Beattie, K. Joncour and A. Wright. 2004. Ultra-performance liquid chromatography coupled to quadrupoleorthogonal time-of-flight mass spectrometry. Rapid Commun. Mass Spectrom. 18(19): 2331-2337.

[35] Hommes, F. A. 1991. Techniques in Diagnostic Human Biochemical Genetics: A Laboratory Manual; Wiley-Liss, New York.

[36] Niwa, T. 1995. Procedures for MS analysis of clinically relevant compounds. Clin. Chim. Acta. 241-242: 75-152.

[37] Halket, J. M., D. Waterman, A. M. Przyborowska, R. K. Patel, P. D. Fraser and P. M. Bramley. 2005. Chemical derivatization and mass spectral libraries in metabolic profiling by GC/MS and LC/MS/MS. J. Exp. Bot. 56(410): 219243.

[38] Philipeon, J. D. 2001. Phytochemistry and medicinal plants. Phytotherapy. 56: 237-243.

[39] Kong, J. M., N. K. Goh, L. S. Chia and T. F. Chia. 2003. Recent advances in traditional plants drugs and orchids. Acta Pharmacologia Scinc. 24: 7-21.

[40] Westh, H., C.S. Zinn and V.T. Rosdah. 2004. An international multicenter study of antimicrobial consumption and resistance in Staphylococcus aureus isolates from 15 hospitals in 14 countries. Microb. Drug Resist. 10:169-176. [41] Bandow, J.E., H. Brotz and L.I.O. Leichert. 2003. Proteomic approach to understanding antibiotic action. Antimicrob. Agents Chemother. 47:948955.

[42] Rojas, R., B. Bustamante and J. Bauer. 2003. Antimicrobial activity of selected Peruvian medicinal plants. J. Ethnopharmacol. 88:199-204.

[43] Benkeblia, N. 2004. Antimicrobial activity of essential oil extracts of various onions (Allium cepa) and garlic (Allium sativum). Lebensm-Wiss u-Technol. 37:263-268.

[44] Iwu, M. W., A. R. Duncan and C. O. Okunji. 1999. New antimicrobials of plant origin. In. J. Janick (Ed). Perspectives in New Crops and New Uses, ASHS Press, Alexandria V.A. Pp. 457-462.

[45] Gupta. R., B. Gabrielsen and F. M. Ferguson1. 2005. Nature's Medicines: Traditional Knowledge and Intellectual Property Management. Case Studies from the National Institutes of Health (NIH), USA Current Drug Discovery Technologies. 2: 203-219.

[46] Gurib-Fakim, A. 2005. Medicinal plants: Traditions of yesterday and drugs of tomorrow. Mol.Aspects Med. 27: 1-93.

[47] Lesney, M. S. 2004. Nature's Pharmaceuticals: Natural Products from Plants Remain at the Core of Modern Medicinal Chemistry. TCAW. 13(7): 26-31.

[48] Shoemaker, M., B. Hamilton, S.H. Dairkee, I. Cohen and M.J. Campbell. 2005. In vitro Anticancer Activity of Twelve Chinese Medicinal Herbs. Phytother. Res. 19:649-651.

[49] Pezzuto, J.M. 1997. Plant-derived anticancer agents. Biochem. Pharmacol. 53: 121-133.

[50] Rai, M. and D. Mares. 2003, Plant-derived antimycotics: current trends and future prospects. Food Products Press, Haworth Press, New York, 587p. [51] Newman, D.J., Cragg, G.M. and K.M. Snader. 2003. Natural products as sources of new drugs over the period 1981-2002. J. Nat. Prod. 66(7): 10221037.

[52] Lucca, A.J.D. and T.J. Walsh. 2000. Antifungal peptides: Novel therapeutic compounds against emerging pathogens. Antimicrob. agents chemother. 43 $1-11$.

[53] Block, G., B. Patterson and A. Subar. 1992. Fruit, vegetables, and cancer prevention: a review of epidemiological evidence. Nutr. Cancer. 18: 1-29.

[54] Minja, M.M.J. 1994. Medicinal Plants used in the promotion of animal health in Tanzania. Rev. Sci. Tech. Off. Int. Epiz. 13(3): 905-925.

[55] Mtambo, M.M, E.J. Mushi, L.D. Kinabo, A. Maeda-Machangu, G.L. Mwamengele, M.G. Yongolo and R.P. Temu. 1999. Evaluation of the efficacy of the crude extracts of Capsicum frutescens, Citrus limon and Opuntia vulgaris against Newcastle disease in domestic fowl in Tanzania. J. Ethnopharmacol. 68(1-3): 55-61.
[56] Bruneton, J. 1995. Pharmacognosy, Phytochemistry, Medicinal plants. France: Lavoisiler Publishing Co., pp. 265-380.

[57] Ahmad, I., Z. Mehmood and F. Mohammad. 1998. Screening of some Indian medicinal plants for their antimicrobial properties. J. Ethnopharmacol. 62: 183-193.

[58] Ahmad, I. and A.Z. Beg. 2001. Antimicrobial and phytochemiacl studies on 45 Indian medicinal plants against multi-drug resistant human pathogens. J. Ethnopharmacol. 74: 113-123.

[59] Vaidya, A.B. 1994. Terminalia arjuna in cardiovascular therapy. J. Assoc. Physicians India. 42: 281-282.

[60] Vlietinck, A.J., L. Van Hoof, J. Totte, A. Lasure, D.V. Berghe, P.C. Rwangabo and J. Mvukiyumwami. 1995. Screening of hundred Rwandese medicinal plants for antimicrobial and antiviral properties. J. Ethnopharmacol. 46: 3147.

[61] Lombardino, J. G. and J. A. Lowe. 2004. The role of the medicinal chemist in drug discovery - then and now. Nat. Rev. Drug Discov. 3(10): 853-862.

[62] Griggs, B. 1981. Green Pharmacy, a history of herbal medicine; J. Norman \& Hobhouse Ltd.; London.

[63] Okigbo, R.N. and A. N. Ajalie. 2005. Inhibition of some Human pathogens with Tropical Plant extracts. Int. J. Mol. Med. 1(1): 34-41.

[64] WHO, 2002. Traditional medicine stratergy 2002-2005. WHO publications (2002) pp. 1-6.

[65] Bader, A., F. Martini, G. R. Schinella, J. L. Rios and J. M. Prieto. 2015. Modulation of cox-1, 5-, 12-and 15-lox by popular herbal remedies used in southern italy against psoriasis and other skin diseases. Phytotherapy Research. 29(1): 108-113.

[66] Haq, I. 2004. Safety of medicinal plants. Pak. J. Med. Res. 43(4): 153156.

[67] Vandavasi, S. R., M. Ramaiah and P. N. Gopal. 2015. In vitro standardization of flowers of methanolic extract of Dendrobium normale falc. For free radical scavenging activity. Journal of Pharmacognosy and Phytochemistry. 3(5): 107-111.

[68] WHO. 2001. Legal status of Traditional Medicines and complementary/ Alternative Medicine: A worldwide review. Geneva, Switzerland.

[69] Zhang, B. B. and D. E. Moller. 2000. New approaches in the treatment of type 2 diabetes. Curr Opin Chem Biol. 4: 461-467.

[70] Tariq, A., S. Mussarat and M. Adnan. 2015. Review on ethnomedicinal, phytochemical and pharmacological evidence of Himalayan anticancer plants. Journal of Ethnopharmacology. 164: 96-119.

[71] Zhang, L. B. and M. G. Gilbert. 2015. Comparison of classifications of vascular plants of china. Taxon. 64(1): 17-26

[72] Shinwari, Z. K., S. Malik, A. M. Karim, R. Faisal and M. Qaiser. 2015. Biological activities of commonly used medicinal plants from Ghazi Brotha, Attock district. Pak. J. Bot. 47(1): 113-120.

[73] Bhardwaj, S. and S. K. Ghakar. 2005. Ethnomedicinal plants used by the tribals of Mizoram to cure cut and wound. Indian J. Tradit. Know. 4(1): 7580.

[74] Khan, S. W. and S. Khatoon. 2008. Ethnobotanical studies on some useful herbs of Haramosh and Bugrote valleys in Gilgit, Northern areas of Pakistan Pak. J. Bot. 40(1): 43-58.

[75] Leporatti, M. L. and E. Lattanzi. 1994. Traditional Phytotherapy on Coastal Area of Makran (Southern Pakistan). Fitoterapia. 65(2): 158-161.

[76] Goodman, S. M. and A. Ghafoor. 1992. The Ethnobotany of Southern Balochistan, Pakistan with particular reference to Medicinal plants. Fieldiana. Bot. 31: 1-84.

[77] Shinwari, Z. K. 2010. Medicinal plants research in Pakistan. J. Med. Plants Res. 4(3): 161-176.

[78] Dastagir, G. 2001. Medicinal Plants of Mai Dhani Hill, Muzaffarabad, Azad Jammu and Kashmir, Hamdard Medicus. 44: 29-35.

[79] Bukhari, S. A. H. 1996. Community uses of medicinal plants, National Park Machyara, Muzaffarabad. Proceedins of First Training Workshop. Ethno. and Appl. (Ed.): Z.K. Shinwari. Conservation NARC: 59-66.

[80] Khan, M. H. 1996. Phytosociological studies of Babusar Valley, Diamer District. Pak. J. Pl. Sci. 2: 79-89.

[81] Rasool, G. 1998. Medicinal plants of Northern areas of Pakistan National Herbarium, (PASA (NARC) Islamabad, Pakistan). 1-68.

[82] Gorsi, M. S. and R. Shahzad. 2002. Medicinal uses of plants with particular reference to the people of Dhirkot. Asian J. Pl. Sci. 1: 222-223.

[83] Shirin, K., S. Imad, S. Shafiq and K. Fatima. 2010. Determination of major and trace elements in the indigenous medicinal plant Withania somnifera and their possible correlation with therapeutic activity. J. Saudi Chem. Soc. 14: $97-100$

[84] Sharma, K. R., M. Agrawal and M. F. Marshall. 2009. Heavy metals in vegetables collected from production and market sites of a tropical urban area of India. Food Chem. Toxicol. 47: 583-591. 
[85] Sher, H., M. N. Alyemeni, L. Wijaya and A. J. Shah. 2010. Ethnopharmaceutically important medicinal plants and its utilization in traditional system of medicine, observation from the Northern Parts of Pakistan. Journal of Medicinal Plants Research. 4(18): 1853-1864.

[86] Rao, A. R., M. Arshad and M. Shafiq. 1989. Perennial grass germplasm of Cholistan desert and its phytosociology. Cholistan Institute of Desert Studies, Islamia University, Bahawalpur, Pakistan, p. 160.

[87] Ali, I., M. S. Chaudhry and U. Farooq. 2009. Camel rearing in Cholistan desert of Pakistan. Pak. Vet. J. 29: 85-92.

[88] Arshad, M., M. Y. Ashraf, M. Ahamad and F. Zaman. 2007. Morphogenetic variability potential of Cenchrus ciliaris L., from Cholistan desert, Pakistan. Pak. J. Bot. 39: 1481-1488.

[89] Hameed, M., M. Ashraf, F. Al-Quriany, T. Nawaz, M. S. A. Ahmad, A. Younis and N. Naz. 2011. Medicinal flora of the Cholistan desert: a review. Pakistan Journal of Botany. 43: 39-50.

[90] Qureshi, R., M. Maqsood, M. Arshad and A. K. Chaudhry. 2011. Ethnomedicinal uses of plants by the people of kadhi areas of khushab, Punjab, Pakistan. Pakistan Journal of Botany. 43: 121-133.

[91] Arshad, M., M. Ashraf and N. Arif. 2006. Morphological variability of Prosopis cineraria (L.) Druce, from the Cholistan desert, Pakistan. Genet. Resour. Crop Evol. 53:1589-1596.

[92] Chaudhry, M. S., N. Sial and N. A. Chaudhry. 2004. Natural resources and their utilization, with special reference to Cholistan desert, Pakistan. Quart. Sci. Vision. 9: 1-10.

[93] Qureshi, R. and G. R. Bhatti. 2008. Ethnobotany of plants used by the Thari people of Nara Desert, Pakistan. Fitoterapia. 79: 468-473.

[94] Jan, G., Khan, M.A., Jan, F., 2008. Medicinal value of Asteraceae of Dir Kohistan Valley, NWFP, Pakistan. Ethnobot. Leaflets. 12: 620-637.

[95] Nadkarni, K. M. 1982. Indian Meteria Medica, 3rd ed. 2. Popular Book Depot, Bombay, pp. 265-270.

[96] Abbasi, A. M., M. A. Khan, M. Ahmad, M. Zafar, H. Khan, N. Muhammad and S. Sultana. 2009. Medicinal plants used for the treatment of jaundice and hepatitis based on socio-economics documentation. Afr. J. Biotechnol. 8: 1643-1650.

[97] Prajapati, N. D., S. S. Purohit, A. K. Sharma and T. Kumar. 2006. A Handbook of Medicinal Plants. Updesh Purihit for Agrobios, Jodhpur, India. Hindustan Printing Press, Jodhpur, pp. 9-552.

[98] Qureshi, R., A. Waheed, M. Arshad and T. Umbreen. 2009. Medicoethnobnotanical inventory of Tehsil Chakwal, Pakistan. Pak. J. Bot. 41: 529538.

[99] Rehman, A. U., H. M. Said and V. U. Ahmad. 1986. Pakistan Encyclopedia Planta Medica. Hamdard Foundation Pakistan/HEJ Research Institute, Karachi, pp. 15-153.

[100] Ahmad, M., M. A. Khan and R. A. Qureshi. 2003. Ethnobotanical study of some cultivated plants of Chhuchh region (district Attock). Hamdard Medicus. 46: 15-19.

[101] Kirtikar, K. R. and B. D. Basu. 1993. Indian Medicinal Plants. 1, 2, 3 and 4. Periodical Expert Book Agency, Vihar Dehli, India, pp. 580-690.

[102] Ahmad, S., A. M. Kalhoro, Z. Kapadia and Y. Badar. 1993. "Aloe" a biologically active and potential medicinal plants. Hamdard Medicus. 36 109-115.

[103] Tyler, V. E., R. Bradly and J. E. Robers. 1981. Pharmacognosy, 8th ed. K.M. Varghese Company, Bombay, pp. 250.

[104] Shah, G. M. and M. A. Khan. 2006. Common medicinal folk recipes of Siran Valley, Mansehra, Pakistan. Ethnob. Leaflets. 10: 49-62.

[105] Haq, I. and M. Rehman. 1990. Medicinal plants of upper Swat (NWFP) Pakistan. Hamdard Medicus 33, 51-68.

[106] Shinwari, M. I. and M. A. Khan. 1998. Multiple dimensions of ethnobotany and its present status in Pakistan. Hamdard Medicus. 42: 5-10. [107] Nadkarni, K. M. 1976. Indian Meteria Medica, 3rd ed. 1 and 2. Popular Book Depot, Bombay, pp. 225-270.

[108] Abbasi, A. M., G. Dastagir, F. Hussain and P. Sanaullah. 2005 Ethnobotany and marketing of crude drug plants in district Haripur, Pakistan. Pak. J. Plant Sci. 11: 103-114.

[109] Hussain, K., A. Shahzad and S. Z. Hussnain. 2008. An ethnobotanical survey of important wild medicinal plants of Hattar district Haripur, Pakistan. Ethnobot. Leaflets. 12: 29-35.

[110] Rastogi, R. P. and B. N. Mehrotra. 1993. Compendium of Indian Medicinal Plants, vol. 1. CDRI/PID, Lucknow/New Delhi, India, pp. 174-178.

[111] Hamid, S., A. W. Sabir, M. Saleem T. A. Chaudhry. 1998. Medicinal plants of family Distaceae. Hamdard Medicus. 36: 62-63.

[112] Rai, S. K., G. R. Mallavarapu, P. R. Shashi, S. Suchi, S. Digvijay, M. Raghvendra and K. Sushil. 2005. Constituents of the flower oil of Carissa opaca growing in the Aravalli mountain range at New Delhi. Flavour and Fragrance Journal 21, 304-305.

[113] Ganguly, M., M. K. Borthakur, N. Devi and R. Mahanta. 2007. Antifertility activity of the methanolic leaf extract of Cissampelos pareira in female albino mice. J. Ethnopharmacol. 111: 688-691.

[114] Ignacimuthu, S., M. Ayyanar and K. Sankarasivaraman. 2008. Ethnobotanical study of medicinal plants used by the Paliyar tribles Theni district of Tamil Nadu, India. Fitoterapia. 79: 562-568.

[115] Ali, B. H., G. Blunden, O. Musbah, Tanira and A. Nemmar. 2008. Some phytochemical, pharmacological and toxicological properties of ginger (Zingiber officinale Roscoe): a review of recent research. Food Chem. Toxicol. 46: 409-420.

[116] Heinrich, M., J. Barnes, S. Gibbons and E. M. Williamson. 2004 Fundamentals of Pharmacognosy and Phytotherapy. Churchill Livingstone, Elsevier Science Ltd., UK.

[117] Kayani, S., M. Ahmad, S. Sultana, Z. K. Shinwari, M. Zafar, G. Yaseen, M. Hussain and T. Bibi. 2015. Ethnobotany of medicinal plants among the communities of alpine and sub-alpine regions of Pakistan. Journal of ethnopharmacology. 164: 186-202.

[118] Ahmed, I. M., U. A. Nadira, N. Bibi, F. Cao, X. He, G. Zhang and F. Wu. 2015. Secondary metabolism and antioxidants are involved in the tolerance to drought and salinity, separately and combined, in Tibetan wild barley. Environmental and Experimental Botany. 111: 1-12.

[119] Bruneton, J. 1999. Pharmacognosy, Phytochemistry and Medicinal Plants. Intercept. Ltd. England, U.K.

[120] van Wyk, B-E., van B. Oudtshoorn and N. Gericke. 2000. Medicinal plants of South Africa, 2nd ed. Briza Publications, Pretoria, South Africa.

[121] Talapatra, S. K., and B. Talapatra. 2015. Reserpine. In Chemistry of Plant Natural Products (pp. 875-890). Springer Berlin Heidelberg.

[122] Hollman, P. C. and M. B. Katan. 1999. Health effects and bioavailability of dietary flavonols. Free Radic. Res. 31(Suppl): S75-S80.

[123] Kumar, S. and A. K. Pandey. 2013. Chemistry and biological activities of flavonoids: An overview. The Scientific World Journal. 2013: 1-16.

[124] Jadhav, B. K., K. R. Khandelwal, A. R. Ketkar and S. S. Pisal. 2004. Formulation and evaluation of mucoadhesive tablets containing eugenol for the treatment of periodontal diseases. Drug Dev. Ind. Pharm. 30(2): 195-203.

[125] Heinrich, M., J. Kufer, M. Leonti and M. Pardo-de-Santayana. 2006. Ethnobotany and ethnopharmacology-Interdisciplinary links with the historical sciences. J. Ethnopharmacol. 107: 157-160.

[126] Musarurwa, H. T., J. van Staden and N. P. Makunga. 2010. In vitro seed germination and cultivation of the aromatic medicinal Salvia stenophylla (Burch. ex Benth.) provides an alternative source of $\alpha$-bisabolol. Plant Growth Regul. 61(3): 287-295.

[127] Vila, R., A. I. Santana, R. Perez-Roses, A. Valderrama, M. V. Castelli, S. Mendonca, S. Zacchino, M. P. Gupta and S. Canigueral. 2010. Composition and biological activity of the essential oil from leaves of Plinia cerrocampanensis, a new source of $\alpha$-bisabolol. Bioresource Technol. 101(7): 2510-2514.

[128] Yagi, A., A. Kabash, N. Okamura, H. Haraguchi, S. M. Moustafa and T. I. Khalifa. 2002. Antioxidant, free radical scavenging and anti-inflammatory effects of aloesin derivatives in Aloe vera. Planta Medica. 68(11): 957-960.

[129] Dell-Agli, M., F. Giavarini, P. Ferraboschi, G. Galli and E. Bosisio. 2007. Determination of aloesin and aloeresin a for the detection of aloe in beverages. Journal of agricultural and food chemistry. 55(9): 3363-3367.

[130] Gou, J., Y. Zou and J. Ahn. 2011. Enhancement of antioxidant and antimicrobial activities of Dianthus superbus, Polygonum aviculare, Sophora flavescens, and Lygodium japonicum by pressure-assisted water extraction. Food Sci. Biotechnol. 20(1): 283-287.

[131] Donini, M., C. Lico, S. Baschieri, S. Conti, W. Magliani, L. Polonelli and E. Benvenuto. 2005. Production of an engineered killer peptide in Nicotiana benthamiana by using a Potato virus X expression system. Appl. Environ. Microbiol. 71: 6360-6367.

[132] Ferre, R., E. Badosa, L. Feliu, M. Planas, E. Montesinos and E. Bardaj. 2006. Inhibition of Plant-Pathogenic Bacteria by Short Synthetic Cecropin A-Melittin Hybrid Peptides. Appl. Environ. Microbiol. 72(5): 3302-3308.

[133] Mee Do, H., S. C. Lee, H.W. Jung, K.H. Sohn and B.K. Hwang. 2004. Differential expression and in situ localization of a pepper defensin (CADEF1) gene in response to pathogen infection, abiotic elicitors and environmental stresses in Capsicum annuum. Plant Science. 166(5): 12971305.

[134] Hwang, B.K. 2001. Cytology, physiology and molecular genetics of resistance to Phytophthora blight in pepper plants. Plant Pathol. J. 17(1): 9-21.

[135] Rushton, P. J. and I. E. Somssich. 1998. Transcriptional control of plant genes responsive to pathogens. Curr. Opin. Plant. Biol. 1: 311-315.

[136] Ecker, J. R. 1995. The ethylene signal transduction pathway in plants. Science. 268: 667-675.

[137] Durner, J., J. Shah and D. F. Klessig. 1997. Salicylic acid and disease resistance in plants. Trends Plant Sci. 2: 266-274. 
[138] Creelman, R. A. J. E. Mullet. 1997. Biosynthesis and action of jasmonates in plants. Annu. Rev. Plant Physiol. Plant Mol. Biol. 48: 355-381. [139] Lamb, C. and R. A. Dixon. 1997. The oxidative burst in plant disease resistance. Annu. Rev. Plant Physiol. Plant Mol. Biol. 48: 251-275.

[140] Reymond, P. and E. E. Farmer. 1998. Jasmonate and salicylate as global signals for defense gene expression. Curr. Opin. Plant Biol. 1: 404-411.

[141] Stotz, H. U., J. Thomson and Y. Wang. 2009. Plant defensins: Defense, development and application. Plant signaling \& behavior. 4(11): 1010-1012. [142] Terras, F. R., I. J. Goderis, F. Van Leuven, J. Vanderleyden, B. P. Cammue and W. F. Broekaert. 1992. In vitro antifungal activity of a radish (Raphanus sativus L.) seed protein homologous to nonspecific lipid transfer proteins. Plant Physiol. 100: 1055-1058.

[143] Garcia-Olmedo, F., A. Molina, A. Segura and M. Moreno. 1995. The defensive role of nonspecific lipid-transfer proteins in plants. Trends Microbiol. 3: 72-74.

[144] Bol, J. F., H. J. M. Linthorst and B. J. C. Cornelissen. 1990. Plant pathogenesis-related proteins induced by virus infection. Annu. Rev. Phytopathol. 28: 113-138.

[145] Alexander, D., R. M. Goodman, M. Gut-Rella, C. Glascock, K. Weymann, L. Friedrich, D. Maddox, P. Ahl-Goy, T. Luntz, E. Ward and J. Ryals. 1993. Increased tolerance to two oomycete pathogens in transgenic tobacco expressing pathogenesis-related protein la. Proc. Natl. Acad. Sci. USA. 90: 7327-7331.

[146] Broekaert, W., B. Cammue, M. De Bolle, K. Thevissen, G. De Samblanx and R. Osborn. 1997. Antimicrobial peptides from plants. Crit. Rev. Plant Sci. 16(3): 297-323.

[147] Bohlmann, H., A. Vignutelli, B. Hilpert, O. Miersch, C. Wasternack and K. Apel. 1998. Wounding and chemicals induce expression of the Arabidopsis thaliana gene Thi2.1, encoding a fungal defense thionin, via the octadecanoid pathway. FEBS Lett. 437: 281-286.

[148] Elfstrand, M., C. G. Fossdal, G. Swedjemark, D. Clapham, O. Olsson, F. Sitbon, P. Sharma, A. Lonneborg and S. von Arnold. 2001. Identification of candidate genes for use in molecular breeding: a case study with the Norway spruce defensin-like gene, SPI1. Silvae. Genet. 50: 75-81.
[149] Chagolla-Lopez, A., A. Blanco-Labra, A. Patthy, R. Sanchez and S. Pongor. 1994. A novel alphaamylase inhibitor from amaranth (Amaranthus hypocondriacus) seeds. J. Biol. Chem. 269: 23675-23680.

[150] Joshi, B. N., M. N. Sainani, K. B. Bastawade, V. S. Gupta and P. K. Ranjekar. 1998. Cysteine protease inhibitor from pearl millet: a new class of antifungal protein. Biochem. Biophys. Res. Commun. 246: 382-387.

[151] Gaspar, Y. M., J. A. McKenna, B. S. McGinness, J. Hinch, S. Poon, A. A. Connelly, M. A. Anderson and R. L. Heath. 2014. Field resistance to Fusarium oxysporum and Verticillium dahliae in transgenic cotton expressing the plant defensin NaD1. Journal of experimental botany. 65(6): 1541-1550.

[152] Sanon, S., N. Azas, M. Gasquet, E. Ollivier, V. Mahiou, N. Barro, N. Cuzin-Ouattara, A. S. Traore, F. Esposito, G. Balansard and P. Timon-David. 2003. Antiplasmodial activity of alkaloid extracts from Pavetta crassipes (K. Schum) and Acanthospermum hispidum (DC), two plants used in traditional medicine in Burkina Faso. Parasitol. Res. 90: 314-317.

[153] Sanon, S., V. Mahiou, I. Nebie, N. Azas, E. Ollivier, P. Timon-David, G. Balansard and A. S. Traore. 2005. In vitro antimalarial properties of two plants used by traditional herbal practitioners of Burkina Faso: Pavetta crassipes and Mitragyna inermis. Acta Tropica. 95: 1-506.

[154] Balde, E.S., V. Megalizzi, M. Cao, L. Angenot, R. Kiss, M. Van Damme and M. Frederich. 2010. Isostrychnopentamine, an indolomonoterpenic alkaloid from Strychnos usambarensis, with potential anti-tumor activity against apoptosis-resistant cancer cells. Int. J. Oncol. 36: 961-965.

[155] van Der Heijden, R., D. I. Jacobs, W. Snoeijer, D. Hallard and R. Verpoorte. 2004. The Catharanthus alkaloids: pharmacognosy and biotechnology. Curr. Med. Chem. 11(5): 607-628.

[156] Okouneva, T., B. T. Hill, L. Wilson and M. A. Jordan. 2003. The effects of vinflunine, vinorelbine, and vinblastine on centromere dynamics. Mol. Cancer Ther. 2(5): 427-436.

[157] Horwitz, S.B. 2004. Personal recollections on the early development of taxol. J. Nat. Prod. 67(2): 136-138.

[158] Gordaliza, M., P. A. Garcia, J. M. del Corral, M. A. Castro, M. A. GomezZurita. 2004. Podophyllotoxin: distribution, sources, applications and new cytotoxic derivatives. Toxicon. 44(4): 441- 459. 